\title{
Characterization of Ultrapure Germanium (9N) Using a Wet Chemical Method for ICP-QMS and HR-CS-GFAAS Analysis
}

\author{
M.A. Reddy, R. Shekhar*, and Sunil Jai Kumar \\ National Centre for Compositional Characterization of Materials (NCCCM) \\ Bhabha Atomic Research Centre, Hyderabad 500 062, India
}

\begin{abstract}
A wet chemical method is reported to characterize ultrapure germanium $(\mathrm{Ge})$ of $9 \mathrm{~N}$ (99.9999999\%) purity. In this method, matrix germanium is separated from all its impurities with a matrix volatilization procedure. Chlorine gas is generated in situ and reacts with Ge solid material directly at the temperature of $230 \pm 5^{\circ} \mathrm{C}$ and separates the $\mathrm{Ge}$ matrix as volatile $\mathrm{GeCl}_{4}$ from all its impurities. Further modifications were done to the matrix volatilization setup earlier used for $8 \mathrm{~N}$ pure Ge to further control the contamination of the atmospheric gases to the $9 \mathrm{~N}$ pure Ge sample during the different stages of matrix volatilization. After modifications, the method provides sub parts per billion and parts per trillion levels of process blanks and extremely low limits of detection.
\end{abstract}

More than 60 elements were examined for their separation from the Ge matrix using the proposed method and found to be quantitatively separated. Determination of impurity concentrations was performed by inductively coupled plasma quadrupole mass spectrometer (ICP-QMS) and high resolution continuum source graphite furnace atomic absorption spectrometer (HR-CS-GFAAS). In the absence of certified reference materials for ultrapure Ge, accuracy of the present method was established by spike recovery tests. Precision of this method was between 4 to $10 \%$ for impurity concentrations from 0.28 to $0.011 \mathrm{ng} \mathrm{g}^{-1}$. Limits of detection (LOD) were found between 4.6$0.005 \mathrm{ng} \mathrm{mL}^{-1}$ or $1.4-0.002 \mathrm{ng} \mathrm{g}^{-1}$ for the target analytes. The wet chemical method was found to be useful for the characterization of ultrapure Ge material of $9 \mathrm{~N}$ purity.

\section{INTRODUCTION}

Germanium (Ge) material finds many applications in the electronic industry for transistors, high-speed integrated circuits (SiGe), solar electrical parts, etc. High pure Ge material is extensively used in gamma ray spectroscopy, the electronics industry, for medicine and phosphor agents in fluorescent lamps, polymerization catalysts, is being used in extremely sensitive infrared detectors and gamma-ray detectors, and offers certain advan-

\footnotetext{
*Corresponding autbor.

E-mail: Shekbar_rapartbi@rediffmail.com

Tel: +91 40-27121365?

Fax: $+9140-2712463$
}

tages over GaAs: high mechanical strength, high crystallographic perfection and the ability to recycle Ge. These factors have led to a wide use of Ge wafers as a substrate for GaAs for telecommunication satellites (5). Generally, the refining method is used to make at least a 6N (99.9999\%) purity Ge. Impurities present in the Ge materials can act as traps for electron-hole pairs and also produce deep-level states in the band-gap, which can act as recombination centers or carrier traps, thereby degrading the performance of semiconductor devices (6-7).

Therefore, analysis of ultrapure Ge is essential to meet the challenges and highest demands in the global market. A number of analytical techniques have been developed for the determination of trace constituents in pure Ge. Neutron activation analysis (NAA) (8-9), photoelectron spectroscopy (10), atomic absorption spectrometry (AAS) (1113), atomic emission spectrometry (AES) (14), and spark source mass spectrometry (11) are among the analytical techniques used for the characterization of pure Ge.

The sensitive and multi-elemental analytical technique of inductively coupled plasma mass spectrometry (ICP-MS) can determine concentrations of impurities at trace and ultra-trace levels, but can tolerate solutions containing only up to a maximum of $0.1 \%$ total dissolved solids (15-17). This drawback demands separation of the Ge matrix from its impurities. Chemical separation of the matrix from all other minor or trace constituents is not possible in a single step. Many separation procedures found in the literature are suitable only for a group of elements at a time. Thus, trace element group separations using co-precipitation, solvent extraction, and ion exchange methods are often required.

To separate the Ge matrix as $\mathrm{GeCl}_{4}$ from its impurities, a distillation method was used (18). A closed-vessel microwave-assisted volatilization of Ge and Se as their chlorides in the presence of aqua regia vapors and determination by ICP-MS was reported later (19). In addition, two different matrix separation procedures were reported (20) for the determination of critical impurities such as $\mathrm{Cr}, \mathrm{Cu}, \mathrm{Fe}$, $\mathrm{Ni}$, and $\mathrm{Pb}$ in a Ge matrix by using 
GFAAS. One procedure (20) involved cloud point extraction, which used the ammonium pyrrolidine dithiocarbamate (APDC) Triton ${ }^{\circledR} \mathrm{X}-114$ system, and another procedure (20) used a matrix volatilization technique for the removal of the Ge matrix with chlorine gas and determination by GFAAS. However, only a few impurity elements ( $\mathrm{Cr}, \mathrm{Cu}, \mathrm{Fe}, \mathrm{Ni}, \mathrm{Pb}$ ) were quantified by both procedures and their results compared (21). Later, nearly 40 impurities were quantified in high pure Ge of $6 \mathrm{~N}$ purity using the matrix volatilization method (21).

Niemela et al. (22) published a procedure on the determination of trace impurities in Ge oxide by ICPMS, electrothermal AAS, and ICP optical emission spectrometry (OES) after matrix volatilization. But only 15 impurity elements were quantified. These authors used the open-vessel digestion and openvessel evaporation of the Ge matrix which attracted the external contamination. Hence, the procedure can be applicable only up to the purity of around $6 \mathrm{~N}$ even after using a quartz digestion vessel. Petrova el al. (23) reported another procedure on the analysis of high purity Ge oxide by AAS; however, only seven elements were reported. The procedure involved Ge separation through reactive evaporation in the form of Ge tetrachloride in an open system and offers an analysis of around $6 \mathrm{~N}$ purity material only. As the purity of the Ge increases, the process blank levels of an analytical method restricts the quantification of the impurities in high pure materials.

Recently, a modified matrix volatilization method was reported by controlling the transport of chlorine gas using a mass flow controller at a reaction temperature of $120 \pm 5^{\circ} \mathrm{C}$ with chlorine gas for the determination of impurities in high purity Ge of purity up to $7 \mathrm{~N}$ (24).
However, this method (24) was not found to be suitable for the determination of impurities in $8 \mathrm{~N}$ pure Ge and as the purity of the material increases, the levels of the impurities will be at extremely low levels, and also the chemistry of the material may not be identical. More recently, an improved matrix separation method was described for the characterization of ultrapure $\mathrm{Ge}$ of $8 \mathrm{~N}$ purity by optimizing the reaction temperature to $230 \pm 5^{\circ} \mathrm{C}$ with chlorine gas (25). The reported total process blank levels of this method (25) revealed that it cannot be useful for the characterization of ultrapure Ge of $9 \mathrm{~N}$ purity. As the purity of the material further increases, the levels of the impurities will be at extremely low levels and hence, it becomes a great challenge for the chemists to control the process blank levels of a wet chemical method below the levels of the impurities present at such an extremely low level without any contamination and matrix-related problems. So far to our knowledge, there are no reports in the literature about the determination of impurities in ultrapure Ge $(>8 \mathrm{~N})$ by wet chemical methods.

In this paper, a wet chemical method is reported for the characterization of ultrapure Ge of $9 \mathrm{~N}$ purity for its impurity concentrations by ICP-QMS and GFAAS. Different modifications were made at the various stages of the matrix volatilization setup to minimize the contamination of atmospheric gas during the chemical process steps for Ge matrix separation for $9 \mathrm{~N}$ pure Ge. With the proposed method, the recovery of more than 60 elements and their process blank levels and limits of detection are examined. The analytical applications are described in detail in this article. The reported method is found to be useful for chemical characterization of ultrapure Ge (9N) materials. Quantification is performed by ICP-QMS as the levels of many of the impurities are at the sub parts per billion levels. The elements that suffer from potential spectral interferences due to the discharge gas and the Ge matrix have been identified in ICP-QMS analysis and are quantified by an alternative sensitive analytical technique, graphite furnace atomic absorption spectrometry (GFAAS). Salient features of the proposed method are reported.

\section{EXPERIMENTAL}

\section{Instrumentation}

Determination of the concentrations of impurities in ultrapure Ge were done by an inductively coupled plasma quadrupole mass spectrometer (VG Plasma Quad 3 ICP-QMS, V.G. Elemental, Winsford, Chesire, UK). The operating parameters of the ICP-QMS were optimized for maximum sensitivity using a $10 \mathrm{ng} \mathrm{mL}^{-1}$ tuning solution of $\mathrm{Be}, \mathrm{Co}, \mathrm{Rh}$, In, and $\mathrm{Bi}$ in $2 \%(\mathrm{v} / \mathrm{v})$ $\mathrm{HNO}_{3}$, introduced at a flow rate of $0.8 \mathrm{~mL} \mathrm{~min}^{-1}$ using a peristaltic pump (REGLO Digital MS-4/12, ISMATEC, Switzerland). The instrumental parameters and typical measurement parameters of the ICP-QMS are listed in Table I.

Sample introduction was carried out by pneumatic nebulization using a Meinhard ${ }^{\circledR}$ concentric nebulizer and a double-pass Scott-type spray chamber cooled to $5^{\circ} \mathrm{C}$ using a NESLAB recirculating chiller and a Fassel-type torch. Rhodium was used as the internal standard for all of the samples. Mass spectra were obtained in the peak jumping mode. The 3-mL screw cap PFA (perfluoroalkoxy) containers were cleaned using an Evapo-Cleaner (Analog, Junior Evapo Clean, France) with the mixed acid solution of $250 \mathrm{~mL}$ concentrated $\mathrm{HNO}_{3}$ and $250 \mathrm{~mL}$ concentrated $\mathrm{HCl}$ at $75^{\circ} \mathrm{C}$ for about 4 hours, then was further cleaned using Millipore ${ }^{\circledR}$ Milli-Q ${ }^{\circledR}$ water obtained with a purification system (Millipore, Ban- 
galore, India) for 3 to 4 times and used for the Ge sample analyses.

The analytes Fe, Ga, Sr, Ag, and $\mathrm{Sb}$, which are isobarically interfered, were determined by HR-CSGFAAS (Contra AA 700, Analytik Jena AG, Jena, Germany). Also used were a transversely heated graphite tube, MPE 60 autosampler, and Xenon short arc lamp in hot-spot mode operated at $300 \mathrm{~W}$ as a continuum radiation source. A highresolution double monochromator consisting of a prism and an echelle grating monochromator, providing a spectral bandwidth per pixel of ca. $2 \mathrm{pm}$ at $200 \mathrm{~nm}$, was used and a linear charge coupled device array detector of total 588 pixels, out of which 200 pixels were used for the determination of dispersed radiation. The analyte's absorptions were measured using the central pixel $(C P) \pm 1$ pixels, i.e., over a spectral interval of approximately $6 \mathrm{pm}$. Argon, with a purity of $99.99 \%$, was used as the purge gas in all stages, except during the atomization step. The sample volume was $10 \mu \mathrm{L}$.

The optimized furnace programs used for the determination of these elements are given in Table II. Fast heating for the pyrolysis process was required to expel the unwanted matrix and to retain the analyte. This program was established by instrument manufacturer and given in the instrument manual. Absorption measurement was made at the analytical wavelength of $248.327 \mathrm{~nm}$ for Fe, $287.424 \mathrm{~nm}$ for $\mathrm{Ga}$,

$460.731 \mathrm{~nm}$, for $\mathrm{Sr}, 328.068 \mathrm{~nm}$, for $\mathrm{Ag}$ and $\mathrm{Sb} 217.682 \mathrm{~nm}$. The modifiers used for the analysis were $\mathrm{Mg}$ for Fe, Pd for Ga, Pd-Mg for Ag, Sb and no modifier for $\mathrm{Sr}$. The $\mathrm{Mg}$ chemical modifier was needed for Fe also to prevent the loss of Fe during the pyrolysis process, and subsequently to get maximum signal for Fe. An inductively coupled plasma optical emission spectrometer (Model JY-2000, Jobin-Yvon,
France) was used to measure the content of residual Ge in the solution at the wavelength of $265.1 \mathrm{~nm}$.

\section{Reagents and Standard Solutions}

Manganese dioxide powder (purity $>89 \%$ ) and stock standards

\section{Atomic Spectroscopy \\ 1 Vol. 40(1), Jan./Feb. 2019}

of $1 \mathrm{mg} \mathrm{mL} \mathrm{mL}^{-1}$ concentration for each analyte were procured from M/s. Merck, Germany. Sub-boiled acids $\left(\mathrm{HNO}_{3}, \mathrm{HCl}\right)$, prepared in our laboratory using a quartz sub-boiling apparatus (fabricated indigenously at Nuclear Fuel Complex, Hyderabad, India), were used for

TABLE I

ICP-QMS Instrumental Parameters

\begin{tabular}{ll}
\hline Parameter & Optimum Value \\
\hline Plasma RF power & $1300 \mathrm{~W}$ \\
Reflected power & $<0.9 \mathrm{~W}$ \\
Torch type & Fassel $(\mathrm{VG})$ \\
Coolant argon flow rate & $13.5 \mathrm{~L} \mathrm{~min}{ }^{-1}$ \\
Auxiliary argon flow rate & $0.90 \mathrm{~L} \mathrm{~min}{ }^{-1}$ \\
Nebulizer gas & $0.90 \mathrm{~L} \mathrm{~min}{ }^{-1}$ \\
Sample uptake rate & $0.8 \mathrm{~mL} \mathrm{~min}{ }^{-1}$ \\
Ni sample cone orifice & $1.0 \mathrm{~mm}$ \\
Ni skimmer cone orifice & $0.7 \mathrm{~mm}$ \\
Detector mode & $\mathrm{Dual} \mathrm{mode}(\mathrm{PC} / \mathrm{Analog})$ \\
Scanning mode & $\mathrm{Peak} \mathrm{jump}$ \\
Number of replicates & $3 \mathrm{Mp}$ \\
Dwell time & $100 \mathrm{~ms} \mathrm{per} \mathrm{channel}$ \\
Isotopes used & ${ }^{7} \mathrm{Li},{ }^{9} \mathrm{Be},{ }^{26} \mathrm{Mg},{ }^{27} \mathrm{Al},{ }^{45} \mathrm{Sc},{ }^{49} \mathrm{Ti},{ }^{50} \mathrm{~V}$, \\
& ${ }^{71} \mathrm{Gr},{ }^{55} \mathrm{Mn},{ }^{59} \mathrm{Co},{ }^{60} \mathrm{Ni},{ }^{63} \mathrm{Cu},{ }^{64} \mathrm{Zn}$, \\
& ${ }^{88} \mathrm{Rb},{ }^{88} \mathrm{Sr},{ }^{89} \mathrm{Y},{ }^{93} \mathrm{Nb},{ }^{94} \mathrm{Zr}$, \\
& ${ }^{115} \mathrm{In},{ }^{120} \mathrm{Sn},{ }^{121} \mathrm{Ag},{ }^{108} \mathrm{Pd},{ }^{111} \mathrm{Cd}$, \\
& ${ }^{138} \mathrm{Ba},{ }^{139} \mathrm{La},{ }^{140} \mathrm{Ce},{ }^{146} \mathrm{Nd},{ }^{152} \mathrm{Sm}$, \\
& ${ }^{153} \mathrm{Eu},{ }^{158} \mathrm{Gd},{ }^{159} \mathrm{~Tb},{ }^{164} \mathrm{Dy},{ }^{165} \mathrm{Ho}$, \\
& ${ }^{166} \mathrm{Er},{ }^{169} \mathrm{Tm},{ }^{174} \mathrm{Yb},{ }^{175} \mathrm{Lu},{ }^{181} \mathrm{Ta}$, \\
& ${ }^{184} \mathrm{~W},{ }^{187} \mathrm{Re},{ }^{192} \mathrm{Os},{ }^{193} \mathrm{Ir},{ }^{195} \mathrm{Pt}$, \\
& ${ }^{197} \mathrm{Au},{ }^{202} \mathrm{Hg},{ }^{205} \mathrm{Tl},{ }^{208} \mathrm{~Pb},{ }^{209} \mathrm{Bi}$ \\
\hline
\end{tabular}

TABLE II

Temperature Program of HR-CS-GFAAS

\begin{tabular}{|c|c|c|c|c|c|}
\hline Element & $\begin{array}{l}\text { Temperature } \\
\left({ }^{\circ} \mathrm{C}\right)\end{array}$ & $\begin{array}{l}\text { Ramp } \\
\left({ }^{\circ} \mathrm{C} / \mathrm{s}\right)\end{array}$ & $\begin{array}{l}\text { Hold } \\
\text { (s) }\end{array}$ & 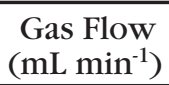 & Read \\
\hline Dry I & 75 & 25 & 8 & 240 & No \\
\hline Dry II & 85 & 25 & 4 & 240 & No \\
\hline Dry III & 105 & 30 & 6 & 240 & No \\
\hline Pyrolysis & $\begin{array}{l}1100(\mathrm{Fe}), 1000(\mathrm{Ga}), \\
1200(\mathrm{Sr}), 700(\mathrm{Ag}), \\
1100(\mathrm{Sb})\end{array}$ & 1400 & 6 & 240 & No \\
\hline Atomization & $\begin{array}{l}2000(\mathrm{Fe}), 2200(\mathrm{Ga}) \\
2450(\mathrm{Sr}), 1600(\mathrm{Ag}), \\
1950(\mathrm{Sb})\end{array}$ & 1400 & 5 & 0 & Yes \\
\hline Cleaning & 2400 & 1500 & 2 & 240 & No \\
\hline
\end{tabular}


all of the experiments. Ultra-pure water ( $>18 \mathrm{M} \Omega-\mathrm{cm}$ resistivity) was obtained with a combination of reverse-osmosis (RO) system mixedbed ion-exchanger and Millipore ${ }^{\circledR}$ Milli-Q ${ }^{\circledR}$ water. The working standards were prepared by sequential dilutions of the stock standards on a day-to-day basis and added with rhodium as an internal standard (10 $\mathrm{ng} \mathrm{mL}^{-1}$ ).

\section{Procedure for Matrix Separation}

The pre-cleaning procedure used to clean the quartz boat, quartz reaction vessel, and PFA (perfluoroalkoxy) sample solution container was performed as follows: The quartz boat and the other containers were thoroughly cleaned with ultrapure water, placed in a mixed solution of $10 \%$ of $\mathrm{HNO}_{3}$ and $10 \%$ of $\mathrm{HCl}$, and heated for 5 hours. Then they were taken out and washed with ultrapure water, further cleaned with acid vapors for 4 hours using the Evapo-Cleaner system in which a mixed solution of concentrated $\mathrm{HNO}_{3}$ and concentrated $\mathrm{HCl}$ was heated to $70{ }^{\circ} \mathrm{C}$ to generate acid vapors. Approximately $10 \mathrm{~g}$ of an ultrapure Ge sample was taken in a pre-cleaned quartz boat on a Class 10 clean room bench. The boat was placed in a cleaned quartz reaction vessel covered tightly with parafilm, and the reaction vessel was taken to the experimental setup (placed in a normal fume hood). Then $50 \mathrm{~g}$ of manganese dioxide was added to $150 \mathrm{~mL}$ of concentrated $\mathrm{HCl}$ in a $2000-\mathrm{mL}$ round-bottom flask, placed into a heating mantel, and heated slowly up to $75-85^{\circ} \mathrm{C}$. As the temperature increases, chlorine gas slowly evolves and passes through two consecutive concentrated $\mathrm{H}_{2} \mathrm{SO}_{4}$ traps along with the argon carrier gas, which was allowed into the setup at a small flow rate $(20 \mathrm{~mL}$ $\mathrm{min}^{-1}$ ) by means of a mass flow controller (Figure 1). This dry chlorine gas was passed into a quartz reaction vessel containing ultrapure Ge sample in a quartz boat. The above reaction vessel was maintained at a temperature of $230 \pm 5{ }^{\circ} \mathrm{C}$ for four and a half hours.

Then, another lot of manganese oxide (50 g) and hydrochloric acid $(150 \mathrm{~mL})$ was added into the roundbottomed flask to generate additional chlorine gas for further reaction with the remaining $\mathrm{Ge}$ sample. The reaction was continued for another 4-1/2 hours. Generation and transfer of the volatile matrix are instantaneous. That is, the in situ generated chlorine gas is immediately transported with the carrier argon gas at a flow rate of $20 \mathrm{~mL} \mathrm{~min}^{-1}$ into the Ge reaction vessel, wherein it reacts with the Ge matrix (layer by layer) and immediately forms volatile Ge tetrachloride at a boiling point of only $84^{\circ} \mathrm{C}$. This Ge tetrachloride is thus immediately pushed out of the reaction vessel with the continuous flow of argon gas and enters into $20 \%$ sodium hydroxide solution, taken in another vessel, wherein it reacts with sodium hydroxide and gets converted into sodium germinate precipitate. It is a continuous process and there is no delay in these processes.

The reaction vessel was cooled to room temperature after complete evaporation of the Ge matrix as a chloride, tightly covered with parafilm, and taken to the Class 10 clean bench; the residue was dissolved with $200 \mu \mathrm{L}$ each of subboiled $\mathrm{HNO}_{3}$ and $\mathrm{HCl}$.

For process blank solution preparation, an empty quartz boat containing an air blank was allowed to react with the in situ generated chlorine gas continuously for nine hours, identical to that of the Ge sample. Then, the air residue was dissolved with $200 \mu \mathrm{L}$ each of subboiled $\mathrm{HNO}_{3}$ and $\mathrm{HCl}$. The process

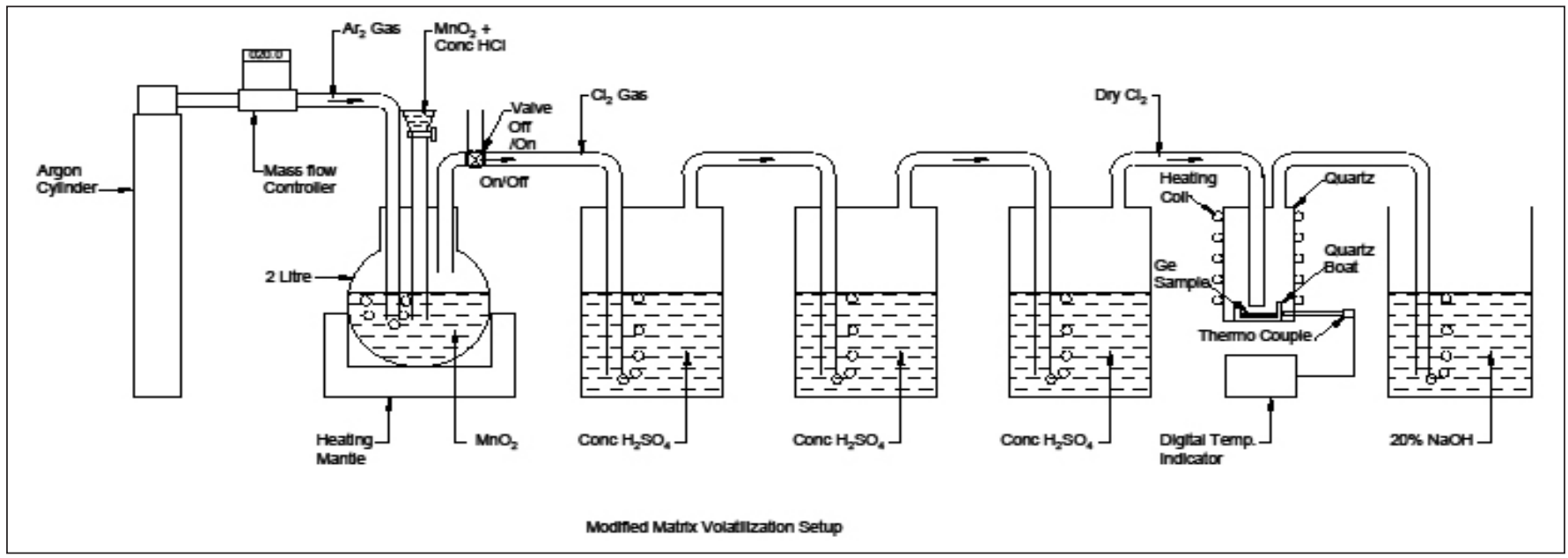

Fig. 1. Further improved matrix volatilization setup (2 L RB flask, extra $\mathrm{H}_{2} \mathrm{SO}_{4}$ trap and one separate valve for controlling atmosphere contamination) for $9 \mathrm{~N}$ pure Ge. 
blank solution and the residual solution of Ge sample containing its trace elements were passed into the ICP-QMS after dilution to $3 \mathrm{~mL}$ and spiking with rhodium as the internal standard. For some of the elements for which the isotopes with the highest abundance suffered from spectral interferences, alternative isotopes of lower abundance having minimum or no isobaric interferences were chosen for quantification. In the ICP-QMS analysis, the isotopes used for quantification of the impurities are given in Table I. The quantification of the trace elements in the Ge sample was done using external calibrations. Some of the elements that suffer from spectral interferences completely in ICP-QMS were analyzed and quantified by GFAAS.

\section{RESULTS AND DISCUSSION}

\section{Fine Controlling of Process Blank Levels}

Earlier, a matrix volatilization method (25) was reported for the separation of Ge matrix from its impurities in $8 \mathrm{~N}$ pure Ge material. In this method, $10 \mathrm{~g}$ of Ge sample was taken into a quartz boat, placed in a quartz reaction vessel, and allowed to react with in situ generated chlorine gas at the optimized reaction temperature of $230 \pm 5^{\circ} \mathrm{C}$ for $4-1 / 2$ hours. Here, the chlorine gas is generated in a round-bottom flask with a first lot of manganese oxide (50 g) and sub-boiled hydrochloric acid $(150 \mathrm{~mL})$. After 4-1/2 hours of chlorine reaction, the second lot of manganese oxide $(50 \mathrm{~g})$ and hydrochloric acid (150 $\mathrm{mL}$ ) was added into the round-bottomed flask through its center port by opening its port to the atmosphere to generate additional chlorine gas for further reaction with the remaining/residual Ge sample (unreacted Ge sample). Then the reaction was continued for another $4-1 / 2$ hours. Matrix separation in this method was found to be
99.95\%. Thus, the earlier matrix volatilization method was applied to the ultrapure $(8 \mathrm{~N})$ Ge sample with the optimized heating time of nine hours and a reaction temperature of $230 \pm 5^{\circ} \mathrm{C}$. However, this method was found to be useful for the determination of impurities in ultrapure Ge material of a purity up to $8 \mathrm{~N}$ only. The main drawback of this method is the limitation of the process blank levels; that is, its total process blank level is around $10 \mathrm{ng} \mathrm{g}^{-1}$. But for the characterization of $9 \mathrm{~N}$ pure Ge, the total process blank level of the method should only be less than $1 \mathrm{ng} \mathrm{g}^{-1}$. Therefore, this matrix volatilization method (25) is further modified to control the process blank levels in order to bring down the process blank levels to the required levels and to enable the determination of $9 \mathrm{~N}$ pure Ge.

Therefore, chlorine generated in the round-bottomed flask of one liter capacity was replaced with a two-liter capacity. This is to further control the transport of the in situ generated chlorine gas. As the volume of the flask increases, more of the in situ generated chlorine gas will be present in the flask and is very slowly transported along with the argon gas towards the Ge material present in the quartz boat.

In addition, a two-way gas valve was introduced into the chlorine gas path between outlet of this round-bottom flask and inlet of the first sulfuric acid trap (Figure 1). This valve prevents the atmosphere gas entering into the sulfuric acid traps during the addition of manganese dioxide and hydrochloric acid into the round-bottom flask at different stages of reaction. That is, just before the addition of manganese dioxide powder, the inlet path to the first sulfuric acid trap is closed using this valve, and simultaneously this valve keeps the outlet path of the round-bottom flask open to the atmosphere (Figure 1).
Simultaneously, argon gas is continuously allowed to pass from the mass flow controller into the round-bottom flask during the addition of $\mathrm{MnO}_{2}$ to minimize the amount of atmosphere gas entering into this flask. After completion of the addition of $\mathrm{MnO}_{2}$ and $\mathrm{HCl}$ through the center port of the round-bottom flask, this port is closed and the argon gas is continuously allowed to pass through this flask and escape into the atmosphere from the outlet port of the round-bottom flask. This process pushes/flushes out the atmospheric gas entered into the round-bottom flask during the addition of $\mathrm{MnO}_{2}$ and $\mathrm{HCl}$. Then, the inlet valve of the first sulfuric acid trap is opened to the outlet port of the round-bottom flask by simultaneously closing the other outlet port of the roundbottom flask to the atmosphere. In addition to these modifications to the matrix volatilization setup, one more sulfuric acid trap is introduced. That is, a total of three sulfuric acid traps were used for the present study. The third trap helps to further separate the small amount of moisture and its associated contamination. The proposed matrix volatilization setup used for the present study is shown in the Figure 1.

\section{Determination of Process Blank Levels and Limits of Detection With Proposed Method}

Initially, the recoveries for all 61 analytes ( $\mathrm{Li}, \mathrm{Be}, \mathrm{Na}, \mathrm{Mg}, \mathrm{Al}, \mathrm{P}, \mathrm{Si}, \mathrm{K}$, Sc, Ti, V, Cr, Mn, Fe, Co, Ni, Cu, Zn, $\mathrm{Ga}, \mathrm{As}, \mathrm{Se}, \mathrm{Rb}, \mathrm{Sr}, \mathrm{Y}, \mathrm{Nb}, \mathrm{Zr}$, Mo, $\mathrm{Ru}, \mathrm{Ag}, \mathrm{Pd}, \mathrm{Cd}$, In, Sn, Sb, Te, Cs, $\mathrm{Ba}, \mathrm{La}, \mathrm{Ce}, \mathrm{Nd}, \mathrm{Sm}, \mathrm{Eu}, \mathrm{Gd}, \mathrm{Tb}, \mathrm{Dy}$, Ho, Er, Tm, Yb, Lu, Ta, W, Re, Os, Ir, Pt, Au, Hg, Tl, Pb, Bi) were examined using the present matrix volatilization method after the above modifications to the setup. The same percentage recoveries were found as in the previous method (25) for all of the analytes. The process blank levels and limits of detection of the analytes are 
important parameters of an analytical method. So the process blank levels and limits of detection of the quantitatively recovered 54 elements were examined: $\mathrm{Li}, \mathrm{Be}, \mathrm{Na}, \mathrm{Mg}, \mathrm{Al}$, $\mathrm{K}, \mathrm{Sc}, \mathrm{Ti}, \mathrm{V}, \mathrm{Cr}, \mathrm{Mn}, \mathrm{Fe}, \mathrm{Co}, \mathrm{Ni}, \mathrm{Cu}$, $\mathrm{Zn}, \mathrm{Ga}, \mathrm{Rb}, \mathrm{Sr}, \mathrm{Y}, \mathrm{Nb}, \mathrm{Zr}, \mathrm{Mo}, \mathrm{Ru}$, Ag, Pd, Cd, In, Sb, Te, Cs, Ba, La, $\mathrm{Ce}, \mathrm{Nd}, \mathrm{Sm}, \mathrm{Eu}, \mathrm{Gd}$, Tb, Dy, Ho, Er, Tm, Yb, Lu, Ta, W, Re, Os, Ir, Pt, $\mathrm{Au}, \mathrm{Pb}, \mathrm{Bi}$. The remaining seven elements (P, Si, As, Se, Sn, Hg, Tl) were lost, along with the Ge matrix, from the reaction vessel (sample quartz boat). For all of the 54 analytes, the process blank levels, limits of detection (LODs), and limits of quantification (LOQs) were evaluated with the proposed matrix volatilization method.

Without Ge sample, the process blank solution was prepared by treating an empty quartz boat with the chlorine gas in the reaction vessel at the temperature of $230 \pm 5^{\circ} \mathrm{C}$ for nine hours. The residue, after bringing it into acidic solution, was analyzed by ICP-QMS and GF-AAS. The signals for each analyte, except iron and arsenic, were recorded by ICP-QMS using the isotopes listed in Table I. Isobaric interferences of polyatomic ions in ICP-QMS analysis such as ${ }^{38} \mathrm{Ar}^{16} \mathrm{O}^{+},{ }^{40} \mathrm{Ar}^{16} \mathrm{O}^{+}$, and ${ }^{40} \mathrm{Ar}^{35} \mathrm{Cl}^{+}$due to the argon gas, atmospheric gases and water, and acids from the solutions were merging with the actual signals of iron and arsenic. Hence, iron and arsenic were analyzed by the alternative sensitive GFAAS analytical technique. Average process blank $(\mathrm{N}=10)$ levels, LODs, and LOQs of the analytes so determined are listed in Table III and IV, respectively.

The total process blank value (of all analytes) determined with the present method is computed to be nearly $18 \mathrm{ng} \mathrm{mL}^{-1}$ (or $5.5 \mathrm{ng} \mathrm{g}^{-1}$ ) (Table III). This reveals that the modified matrix volatilization method at the reaction temperature of $230^{\circ} \mathrm{C}$ with $10 \mathrm{~g}$ of sample using
ICP-QMS/GFAAS detection enables the determination of impurities in ultrapure Ge of purity higher than $8 \mathrm{~N}$ purity, for which the total impurity should be less than $10 \mathrm{ng} \mathrm{g}^{-1}$.

The limit of detection values are a measure of process blank levels as well as the reproducibility of the analyte signals of an analytical method. Hence, the LODs are calculated with the formula: LOD = blk + $3 \sigma$, where blk is the average mean $(\mathrm{N}=10)$ of each analyte content in the blank measurements and $\sigma$ is the standard deviation of the corresponding process blank measurements for each element. The LOQs are calculated with the formula: LOD $=$ blk $+10 \sigma$ (26). The LODs and LOQs, in $\mathrm{ng} \mathrm{mL}^{-1}$ as well as in ng $\mathrm{g}^{-1}$, obtained for the proposed method are listed in Table IV. These LODs and LOQs are found to be at the ppb to sub-ppb levels. The limits of detection for the target analytes are found to be between 4.6 $0.005 \mathrm{ng} \mathrm{mL}^{-1}$ or $1.4-0.002 \mathrm{ng} \mathrm{g}^{-1}$ for the proposed procedure.

\section{Application of Proposed Wet Chemical Method to Ultrapure Germanium Material (9N)}

$10 \mathrm{~g}$ of an ultrapure Ge material expected to be around $9 \mathrm{~N}$ pure was analyzed using the proposed wet chemical method at the reaction temperature of $230{ }^{\circ} \mathrm{C}$. The Ge matrix was separated from all its impurities using the proposed method as given in the Procedure section. The impurities were taken into mixed solution of nitric and hydrochloric acids and analyzed by ICP-QMS and GFAAS. Quantification of the impurity elements was done by using the external calibration method. Some specific elements that suffer from spectral interferences in ICP-QMS were analyzed and quantified by GFAAS. Concentrations of the impurities in the ultrapure Ge determined by ICPQMS and GFAAS are given in Table V.

\section{Spectral Interferences and Quantification}

In ICP-QMS analysis, the list of isotopes used for quantification of the impurities is given in Table I. With the residual Ge and acids in the solution, both isotopes of gallium, ${ }^{69} \mathrm{Ga}^{+},{ }^{71} \mathrm{Ga}^{+}$, were overlapped with the signals of the polyatomic ions ${ }^{37} \mathrm{Cl}^{16} \mathrm{O}_{2}{ }^{+}$and ${ }^{70} \mathrm{Ge}^{1} \mathrm{H}^{+}$, respectively. The ICP-QMS signals of three major isotopes of strontium, ${ }^{86} \mathrm{Sr}^{+}$, ${ }^{87} \mathrm{Sr}^{+}$, and ${ }^{88} \mathrm{Sr}^{+}$, were affected by the isobaric interferences from the ions ${ }^{70} \mathrm{Ge}^{16} \mathrm{O}^{+},{ }^{87} \mathrm{Rb}^{+}$, and ${ }^{72} \mathrm{Ge}^{16} \mathrm{O}^{+}$, respectively. The mono-isotope of yttrium, ${ }^{89} \mathrm{Y}$, was also interfered with the signal of ${ }^{73} \mathrm{Ge}^{16} \mathrm{O}^{+}$. For silver, both of its isotopes, ${ }^{107} \mathrm{Ag}^{+}$and ${ }^{109} \mathrm{Ag}^{+}$, were suffering from the isobaric interferences due to ${ }^{72} \mathrm{Ge}^{35} \mathrm{Cl}^{+}$, ${ }^{70} \mathrm{Ge}^{37} \mathrm{Cl}^{+},{ }^{72} \mathrm{Ge}^{37} \mathrm{Cl}^{+}$, and ${ }^{74} \mathrm{Ge}^{35} \mathrm{Cl}^{+}$, respectively. In the case of antimony, two of its isotopes, ${ }^{121} \mathrm{Sb}^{+}$ and ${ }^{123} \mathrm{Sb}^{+}$, were interfered with the polyatomic ions ${ }^{70} \mathrm{Ge}^{35} \mathrm{Cl}^{16} \mathrm{O}^{+}$and ${ }^{72} \mathrm{Ge}^{35} \mathrm{Cl}^{16} \mathrm{O}^{+}$, respectively, formed by the residual Ge, and hydrochloric and nitric acids present in the solution. The isotope of iron $\left({ }^{56} \mathrm{Fe}^{+}\right)$ was suffered from isobaric interferences due to the formation of the polyatomic ions of ${ }^{40} \mathrm{Ar}^{16} \mathrm{O}^{+}$. Except Fe and As, the other (interfered) elements ( $\mathrm{Ga}, \mathrm{Sr}, \mathrm{Y}, \mathrm{Ag}, \mathrm{Sb}$ ) were interfered with the residual Ge only. As the process blank solutions did not contain the Ge matrix, the elements $\mathrm{Ga}, \mathrm{Sr}, \mathrm{Y}, \mathrm{Ag}$, and $\mathrm{Sb}$ were measured by ICP-QMS, whereas Fe and As were measured by GFAAS. For the Ge samples, all of the interfered elements of $\mathrm{Fe}, \mathrm{Ga}, \mathrm{Sr}, \mathrm{Ag}$, and $\mathrm{Sb}$, except yttrium, were quantified by GFAAS only. However, quantification of these elements can be possible by ICP-MS equipped with dynamic reaction cell ${ }^{\mathrm{TM}}$ (DRC ${ }^{\text {TM }}$ ICP-MS).

In the absence of DRC ICP-MS at our laboratory, an alternative sensitive technique of graphite furnace atomic absorption spectrometry (GFAAS) was used for the measurement and quantification of these elements. GFAAS is a sensitive analytical technique, but it is a singleelement analytical technique and 
TABLE III

\begin{tabular}{|c|c|c|c|c|c|c|c|c|c|}
\hline & & & $\begin{array}{l}\text { els of Pro } \\
\text { d Their }\end{array}$ & $\begin{array}{l}\text { ess Blank } \\
\text { mpariso }\end{array}$ & $\begin{array}{l}\text { he Propo } \\
\text { h the Ear }\end{array}$ & $\begin{array}{l}\text { sed Metho } \\
\text { lier Metho }\end{array}$ & $\begin{array}{l}(\mathrm{N}=10) \\
(25)\end{array}$ & & \\
\hline Element & & Proces & Blanks & & Element & & Process & 3lanks & \\
\hline & $\begin{array}{l}\text { Earlier } \\
\left(\text { ng mL }{ }^{-1}\right)\end{array}$ & $\begin{array}{c}\text { Present } \\
\left(\text { ng mL }{ }^{-1}\right)\end{array}$ & $\begin{array}{c}\text { Earlier } \\
\left(\mathrm{ng} \mathrm{g}^{-1}\right)\end{array}$ & $\begin{array}{l}\text { Present } \\
\left(\mathrm{ng} \mathrm{g}^{-1}\right)\end{array}$ & & $\begin{array}{c}\text { Earlier } \\
\left(\mathrm{ng} \mathrm{mL} \mathrm{mL}^{-1}\right)\end{array}$ & $\begin{array}{l}\text { Present } \\
\left.(\mathrm{ng} \mathrm{mL})^{-1}\right)\end{array}$ & $\begin{array}{c}\text { Earlier } \\
\left(\mathrm{ng} \mathrm{g}^{-1}\right)\end{array}$ & $\begin{array}{l}\text { Present } \\
\left(\text { ng g }^{-1}\right)\end{array}$ \\
\hline $\mathrm{Li}$ & 0.39 & 0.28 & 0.11 & 0.084 & $\mathrm{Sb}$ & 0.34 & 0.071 & 0.10 & 0.021 \\
\hline $\mathrm{Be}$ & 0.02 & 0.007 & 0.006 & 0.002 & $\mathrm{Te}$ & 0.07 & 0.036 & 0.021 & 0.011 \\
\hline Mg & 5.2 & 4.5 & 1.5 & 1.3 & Cs & 0.04 & 0.007 & 0.012 & 0.002 \\
\hline $\mathrm{Al}$ & 3.6 & 0.77 & 1.0 & 0.23 & $\mathrm{Ba}$ & 0.69 & 0.48 & 0.20 & 0.14 \\
\hline Sc & 0.08 & 0.078 & 0.024 & 0.023 & $\mathrm{La}$ & 0.04 & 0.019 & 0.012 & 0.006 \\
\hline $\mathrm{Ti}$ & 0.6 & 0.61 & 0.18 & 0.18 & $\mathrm{Ce}$ & 0.04 & 0.056 & 0.012 & 0.017 \\
\hline $\mathrm{V}$ & 1.2 & 0.91 & 0.36 & 0.27 & $\mathrm{Nd}$ & 0.02 & 0.017 & 0.006 & 0.005 \\
\hline $\mathrm{Cr}$ & 1.2 & 0.35 & 0.36 & 0.10 & $\mathrm{Eu}$ & 0.01 & 0.003 & 0.003 & 0.001 \\
\hline $\mathrm{Mn}$ & 2.2 & 1.2 & 0.66 & 0.36 & $\mathrm{Sm}$ & 0.01 & 0.008 & 0.003 & 0.002 \\
\hline $\mathrm{Fe}^{*}$ & 4 & 2 & 1.2 & 0.60 & Gd & 0.01 & 0.007 & 0.003 & 0.002 \\
\hline Co & 0.02 & 0.019 & 0.006 & 0.006 & $\mathrm{~Tb}$ & 0.01 & 0.002 & 0.003 & 0.001 \\
\hline $\mathrm{Ni}$ & 0.78 & 0.53 & 0.23 & 0.15 & Dy & 0.01 & 0.005 & 0.003 & 0.002 \\
\hline $\mathrm{Cu}$ & 0.9 & 0.72 & 0.27 & 0.21 & Ho & 0.01 & 0.002 & 0.003 & 0.001 \\
\hline $\mathrm{Zn}$ & 3.4 & 3.2 & 1.0 & 0.96 & $\mathrm{Er}$ & 0.01 & 0.004 & 0.003 & 0.001 \\
\hline $\mathrm{Ga}$ & 1 & 0.79 & 0.30 & 0.23 & $\mathrm{Tm}$ & 0.01 & 0.002 & 0.003 & 0.001 \\
\hline $\mathrm{Rb}$ & 0.08 & 0.074 & 0.024 & 0.022 & $\mathrm{Yb}$ & 0.01 & 0.006 & 0.003 & 0.002 \\
\hline $\mathrm{Sr}$ & 0.2 & 0.17 & 0.06 & 0.051 & $\mathrm{Lu}$ & 0.01 & 0.014 & 0.003 & 0.004 \\
\hline $\mathrm{Y}$ & 0.01 & 0.011 & 0.003 & 0.003 & $\mathrm{Ta}$ & 0.01 & 0.014 & 0.003 & 0.004 \\
\hline $\mathrm{Zr}$ & 0.36 & 0.34 & 0.10 & 0.10 & W & 0.12 & 0.11 & 0.036 & 0.033 \\
\hline $\mathrm{Nb}$ & 0.2 & 0.027 & 0.06 & 0.008 & $\operatorname{Re}$ & 0.01 & 0.010 & 0.003 & 0.003 \\
\hline Mo & 0.13 & 0.15 & 0.039 & 0.045 & Os & 0.033 & 0.032 & 0.009 & 0.010 \\
\hline $\mathrm{Ru}$ & 0.01 & 0.01 & 0.003 & 0.003 & Ir & 0.01 & 0.010 & 0.003 & 0.003 \\
\hline $\mathrm{Pd}$ & 0.09 & 0.043 & 0.027 & 0.013 & $\mathrm{Pt}$ & 0.07 & 0.071 & 0.021 & 0.021 \\
\hline $\mathrm{Ag}$ & 0.16 & 0.13 & 0.048 & 0.039 & $\mathrm{Au}$ & 0.13 & 0.12 & 0.039 & 0.036 \\
\hline $\mathrm{Cd}$ & 0.1 & 0.098 & 0.03 & 0.029 & $\mathrm{~Pb}$ & 0.4 & 0.38 & 0.12 & 0.11 \\
\hline In & 0.05 & 0.036 & 0.015 & 0.011 & $\mathrm{Bi}$ & 0.1 & 0.11 & 0.03 & 0.033 \\
\hline
\end{tabular}

*by GFAAS.

thus requires a significant amount of time to determine all of the impurities in a Ge sample. Hence, only spectrally interfered elements by ICP-QMS were quantified using GFAAS. However, the sensitivity of GFAAS for yttrium is not very good and hence, yttrium is measured only by ICP-QMS, and its values reported as less than the value in Table V.

Due to the non-availability of certified reference materials for ultrapure Ge, the accuracy of the method was established by spike recovery tests. In order to examine the reliability and accuracy of the results, recovery experiments were carried out for the ultrapure Ge samples by spiking them with standard solutions of all of the analytes before applying the modified matrix volatilization procedure. The recoveries of the majority of the impurities, including $\mathrm{Na}$ and $\mathrm{K}$, were determined and found to be quantitative and also the same as in an earlier work (25). All the quanti- tative recoveries of the analytes demonstrate that the proposed method can be applied for the separation/pre-concentration of the target analytes quantitatively from germanium matrix.

Therefore, in ultrapure Ge samples, the concentrations of 52 analytes ( $\mathrm{Li}, \mathrm{Be}, \mathrm{Mg}, \mathrm{Al}, \mathrm{Sc}, \mathrm{Ti}, \mathrm{V}, \mathrm{Cr}$, $\mathrm{Mn}, \mathrm{Fe}, \mathrm{Co}, \mathrm{Ni}, \mathrm{Cu}, \mathrm{Zn}, \mathrm{Ga}, \mathrm{Rb}, \mathrm{Sr}$, $\mathrm{Y}, \mathrm{Nb}, \mathrm{Zr}, \mathrm{Mo}, \mathrm{Ru}, \mathrm{Ag}, \mathrm{Pd}, \mathrm{Cd}$, In, $\mathrm{Sb}, \mathrm{Te}, \mathrm{Cs}, \mathrm{Ba}, \mathrm{La}, \mathrm{Ce}, \mathrm{Nd}, \mathrm{Sm}, \mathrm{Eu}$, Gd, Tb, Dy, Ho, Er, Tm, Yb, Lu, Ta, 
TABLE IV

Limits of Detection (LODs) of Proposed Method ( $N=10)$ and Their Comparison With Earlier Method (25) and Limit of Quantification (LOQ) Values of Present Method

\begin{tabular}{|c|c|c|c|c|c|c|c|c|c|c|c|c|c|}
\hline Element & 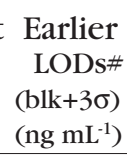 & $\begin{array}{c}\text { Present } \\
\text { LODs\# } \\
(\mathrm{blk}+3 \sigma) \\
\left(\mathrm{ng} \mathrm{mL}^{-1}\right) \\
\end{array}$ & $\begin{array}{r}\text { Earlier } \\
\text { LODs\# } \\
(\mathrm{blk}+3 \sigma) \\
\left(\mathrm{ng} \mathrm{g}^{-1}\right)\end{array}$ & $\begin{array}{c}\text { Present } \\
\text { LODs\# } \\
\text { blk+10б) } \\
\left(\mathrm{ng} \mathrm{g}^{-1}\right)\end{array}$ & $\begin{array}{c}\text { Earlier } \\
\text { LODs\# } \\
(\mathrm{blk}+10 \sigma) \\
\left(\mathrm{ng} \mathrm{g}^{-1}\right) \\
\end{array}$ & $\begin{array}{c}\text { Present } \\
\text { LODs\# } \\
(\mathrm{blk+10 \sigma )} \\
\left(\mathrm{ng} \mathrm{g}^{-1}\right) \\
\end{array}$ & Element & 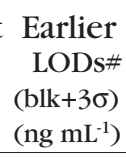 & $\begin{array}{c}\text { Present } \\
\text { LODs\# } \\
(\text { blk }+3 \sigma) \\
\left(\mathrm{ng} \mathrm{mL}^{-1}\right) \\
\end{array}$ & $\begin{array}{r}\text { Earlier } \\
\text { LODs\# } \\
(\mathrm{blk}+3 \sigma) \\
\left(\mathrm{ng} \mathrm{g}^{-1}\right) \\
\end{array}$ & 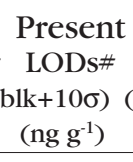 & 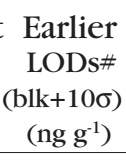 & $\begin{array}{c}\text { Present } \\
\text { LODs\# } \\
(\mathrm{blk}+10 \sigma) \\
\left(\mathrm{ng} \mathrm{g}^{-1}\right) \\
\end{array}$ \\
\hline $\mathrm{Li}$ & 0.40 & 0.28 & 0.12 & 0.087 & 0.31 & 0.093 & $\mathrm{Sb}$ & 0.36 & 0.089 & 0.10 & 0.027 & 0.13 & 0.039 \\
\hline $\mathrm{Be}$ & 0.022 & 0.010 & 0.007 & 0.003 & 0.017 & 0.005 & $\mathrm{Te}$ & 0.079 & 0.060 & 0.024 & 0.018 & 0.11 & 0.035 \\
\hline $\mathrm{Mg}$ & 5.5 & 4.6 & 1.6 & 1.3 & 5.0 & 1.5 & Cs & 0.045 & 0.013 & 0.014 & 0.004 & 0.027 & 0.008 \\
\hline $\mathrm{Al}$ & 4.0 & 1.4 & 1.2 & 0.42 & 2.9 & 0.81 & $\mathrm{Ba}$ & 0.70 & 0.60 & 0.21 & 0.18 & 0.90 & 0.27 \\
\hline Sc & 0.093 & 0.087 & 0.028 & 0.026 & 0.10 & 0.032 & $\mathrm{La}$ & 0.045 & 0.025 & 0.014 & 0.008 & 0.039 & 0.012 \\
\hline $\mathrm{Ti}$ & 0.74 & 0.69 & 0.22 & 0.20 & 0.90 & 0.20 & $\mathrm{Ce}$ & 0.041 & 0.035 & 0.012 & 0.020 & 0.056 & 0.026 \\
\hline V & 1.2 & 0.98 & 0.38 & 0.29 & 1.1 & 0.31 & $\mathrm{Nd}$ & 0.031 & 0.026 & 0.009 & 0.008 & 0.047 & 0.014 \\
\hline $\mathrm{Cr}$ & 1.2 & 0.44 & 0.37 & 0.13 & 0.68 & 0.24 & $\mathrm{Eu}$ & 0.011 & 0.006 & 0.003 & 0.002 & 0.013 & 0.004 \\
\hline Mn & 2.3 & 1.30 & 0.71 & 0.39 & 1.6 & 0.40 & Sm & 0.011 & 0.012 & 0.003 & 0.004 & 0.026 & 0.008 \\
\hline $\mathrm{Fe}^{*}$ & 6.0 & 2.2 & 1.8 & 0.67 & 2.8 & 0.80 & $\mathrm{Gd}$ & 0.011 & 0.010 & 0.003 & 0.004 & 0.027 & 0.008 \\
\hline $\mathrm{Co}$ & 0.022 & 0.025 & 0.007 & 0.008 & 0.039 & 0.012 & $\mathrm{~Tb}$ & 0.011 & 0.005 & 0.003 & 0.002 & 0.012 & 0.004 \\
\hline $\mathrm{Ni}$ & 0.83 & 0.62 & 0.25 & 0.18 & 0.83 & 0.29 & Dy & 0.014 & 0.011 & 0.004 & 0.003 & 0.025 & 0.008 \\
\hline $\mathrm{Cu}$ & 1.0 & 0.85 & 0.32 & 0.25 & 1.1 & 0.38 & Ho & 0.011 & 0.005 & 0.003 & 0.002 & 0.012 & 0.004 \\
\hline $\mathrm{Zn}$ & 3.5 & 3.3 & 1.0 & 1.0 & 3.6 & 1.1 & $\mathrm{Er}$ & 0.011 & 0.007 & 0.003 & 0.002 & 0.014 & 0.004 \\
\hline $\mathrm{Ga}$ & 1.0 & 0.82 & 0.30 & 0.24 & 0.91 & 0.27 & $\mathrm{Tm}$ & 0.011 & 0.005 & 0.003 & 0.002 & 0.012 & 0.004 \\
\hline $\mathrm{Rb}$ & 0.087 & 0.083 & 0.026 & 0.025 & 0.10 & 0.031 & $\mathrm{Yb}$ & 0.011 & 0.012 & 0.003 & 0.004 & 0.026 & 0.008 \\
\hline $\mathrm{Sr}$ & 0.21 & 0.13 & 0.063 & 0.078 & 0.36 & 0.14 & $\mathrm{Lu}$ & 0.011 & 0.011 & 0.003 & 0.005 & 0.019 & 0.007 \\
\hline $\mathrm{Y}$ & 0.012 & 0.013 & 0.004 & 0.004 & 0.016 & 0.005 & $\mathrm{Ta}$ & 0.015 & 0.017 & 0.005 & 0.005 & 0.024 & 0.007 \\
\hline $\mathrm{Zr}$ & 0.40 & 0.37 & 0.12 & 0.11 & 0.47 & 0.14 & W & 0.12 & 0.12 & 0.039 & 0.037 & 0.15 & 0.045 \\
\hline $\mathrm{Nb}$ & 0.21 & 0.036 & 0.063 & 0.011 & 0.057 & 0.017 & $\operatorname{Re}$ & 0.011 & 0.013 & 0.003 & 0.004 & 0.020 & 0.006 \\
\hline Mo & 0.15 & 0.19 & 0.046 & 0.059 & 0.31 & 0.093 & Os & 0.044 & 0.043 & 0.013 & 0.013 & 0.072 & 0.022 \\
\hline $\mathrm{Ru}$ & 0.014 & 0.016 & 0.004 & 0.005 & 0.03 & 0.009 & Ir & 0.012 & 0.012 & 0.004 & 0.006 & 0.033 & 0.012 \\
\hline $\mathrm{Pd}$ & 0.10 & 0.076 & 0.031 & 0.023 & 0.15 & 0.046 & $\mathrm{Pt}$ & 0.087 & 0.10 & 0.026 & 0.031 & 0.18 & 0.054 \\
\hline $\mathrm{Ag}$ & 0.18 & 0.18 & 0.056 & 0.056 & 0.32 & 0.096 & $\mathrm{Au}$ & 0.20 & 0.21 & 0.062 & 0.061 & 0.40 & 0.12 \\
\hline $\mathrm{Cd}$ & 0.11 & 0.10 & 0.035 & 0.034 & 0.14 & 0.044 & $\mathrm{~Pb}$ & 0.42 & 0.41 & 0.12 & 0.12 & 0.52 & 0.15 \\
\hline In & 0.052 & 0.039 & 0.016 & 0.012 & 0.046 & 0.014 & $\mathrm{Bi}$ & 0.12 & 0.12 & 0.036 & 0.037 & 0.16 & 0.048 \\
\hline
\end{tabular}

*: by GF-AAS.

\#: LOD $=$ blk $+3 \sigma$, where blk is the average mean of the each analyte content in the blank measurements and $\sigma$ is the standard deviation of corresponding process blank measurements for each element. $\mathrm{LOQ}=\mathrm{blk}+10 \sigma$.

$\mathrm{W}, \mathrm{Re}, \mathrm{Os}, \mathrm{Ir}, \mathrm{Pt}, \mathrm{Au}, \mathrm{Pb}, \mathrm{Bi})$ were determined by ICP-QMS with GFAAS using the proposed method, the results given in Table $V$. Due to the higher process blank levels of $\mathrm{Na}$ and $\mathrm{K}$, the actual concentrations of these elements in ultrapure Ge could not be quantified. Concentrations of all other impurities in the ultrapure Ge sample were determined using the external calibration method. The concentrations of some of the elements, whose signals were found to be equal to those of the process blanks, were determined based on the average process blank signal and reported as less than values. As the GFAAS signals for $\mathrm{Fe}, \mathrm{Ga}, \mathrm{Sr}, \mathrm{Ag}$, and $\mathrm{Sb}$ in the sample solution were found to be equal to their respective process blank signals, only less than the values (i.e., process blank equivalent concentrations) obtained from their individual process blank concentrations and determined by GFAAS are reported in Table $\mathrm{V}$. The Mn concentration value of $5.3 \mathrm{ng} \mathrm{g}^{-1}$ was mainly due to the carryover of traces of $\mathrm{MnO}_{2}$ (used for the generation of chlorine gas in the matrix volatilization method) into the reaction vessel along with carrier argon gas.

The impurities such as hydrogen, carbon, nitrogen, and oxygen can 
TABLE V

Levels of Impurities in Ultrapure Ge $(9 \mathrm{~N})$

Determined by ICP-QMS and GF-AAS Using Proposed Method (N=4)

\begin{tabular}{ll|ll}
\hline Element & $\begin{array}{c}\text { Concentrations } \\
\left(\mathrm{ng} \mathrm{g}^{-1}\right)\end{array}$ & Element & $\begin{array}{c}\text { Concentrations } \\
\left(\mathrm{ng} \mathrm{g}^{-1}\right)\end{array}$ \\
\hline $\mathrm{Li}$ & $<0.084$ & $\mathrm{Sb}^{\mathrm{b}}$ & $<0.2$ \\
$\mathrm{Be}$ & $<0.002$ & $\mathrm{Te}$ & $<0.011$ \\
$\mathrm{Mg}$ & $<1.3$ & $\mathrm{Cs}$ & $<0.002$ \\
$\mathrm{Al}$ & $<0.23$ & $\mathrm{Ba}$ & $<0.14$ \\
$\mathrm{Sc}$ & $<0.023$ & $\mathrm{La}$ & $<0.006$ \\
$\mathrm{Ti}$ & $<0.18$ & $\mathrm{Ce}$ & $<0.017$ \\
$\mathrm{~V}$ & $0.16 \pm 0.01$ & $\mathrm{Nd}$ & $<0.005$ \\
$\mathrm{Cr}$ & $0.28 \pm 0.01$ & $\mathrm{Sm}$ & $<0.002$ \\
$\mathrm{Mn}$ & $5.3 \mathrm{c}$ & $\mathrm{Eu}$ & $<0.001$ \\
$\mathrm{Fe}$ & $<0.6$ & $\mathrm{Gd}$ & $<0.002$ \\
$\mathrm{Co}$ & $0.053 \pm 0.003$ & $\mathrm{~Tb}$ & $<0.001$ \\
$\mathrm{Ni}$ & $<0.15$ & $\mathrm{Dy}$ & $<0.002$ \\
$\mathrm{Cu}$ & $<0.21$ & $\mathrm{Ho}$ & $<0.001$ \\
$\mathrm{Zn}$ & $<1$ & $\mathrm{Er}$ & $<0.001$ \\
$\mathrm{Ga}$ & $<0.8$ & $\mathrm{Tm}$ & $<0.001$ \\
$\mathrm{Rb}$ & $<0.022$ & $\mathrm{Yb}$ & $<0.002$ \\
$\mathrm{Sr}$ & $<0.3$ & $\mathrm{Lu}$ & $<0.004$ \\
$\mathrm{Nb}$ & $<0.2$ & $\mathrm{Ta}$ & $<0.004$ \\
$\mathrm{Y}$ & $<0.3$ & $\mathrm{~W}$ & $<0.033$ \\
$\mathrm{Zr}$ & $0.063 \pm 0.003$ & $\mathrm{Re}$ & $<0.003$ \\
$\mathrm{Mo}$ & $<0.045$ & $\mathrm{Ir}$ & $<0.003$ \\
$\mathrm{Ru}$ & $0.025 \pm 0.002$ & $\mathrm{Os}$ & $<0.010$ \\
$\mathrm{Pd}$ & $0.040 \pm 0.005$ & $\mathrm{Pt}$ & $<0.021$ \\
$\mathrm{Ag}$ & $<0.3$ & $\mathrm{Au}$ & $<0.036$ \\
$\mathrm{Cd}$ & $<0.029$ & $\mathrm{~Pb}$ & $0.16 \pm 0.02$ \\
$\mathrm{In}$ & $<0.011$ & $\mathrm{Bi}$ & $0.070 \pm 0.003$ \\
\hline $\mathrm{Ge}$ & &
\end{tabular}

${ }^{\mathrm{a}}$ Germanium sample mass is $10 \mathrm{~g}$.

b by GFAAS.

c Carryover of $\mathrm{MnO}_{2}$.

enter into ultrapure Ge from the used gases and the atmosphere.

However, these impurities are neutral impurities in semiconductors (Si and Ge) (27). Little attention has been given to neutral impurities in semiconductors as they do not directly affect the properties that are important in electronic devices (27). Thus, these impurities were not studied and discussed in this paper.

The results listed in Table $\mathrm{V}$ indicate that the concentration of all of the elements are at the sub parts per billion and parts per trillion levels. Table $\mathrm{V}$ also shows that the concentrations of a few elements are definite values and of other elements are less than (limit) values. The limit values indicate that these elements may not be present in the Ge sample, but might have come from process steps of this proposed method, and hence, their signals were found to be equal to that of the process blank levels. Otherwise, these elements might have entered into the Ge sample during the various process steps involved right after the purification of the sample to the final determination of the concentrations in spite of several precautions taken.

Hence, the total concentration of all of the analytes listed in Table $\mathrm{V}$, excluding the elements of limit values, is found to be $0.85 \mathrm{ng} \mathrm{g}^{-1}$. This shows that the Ge sample analyzed with the proposed method has the purity of $9 \mathrm{~N}$ for which a total concentration of all of the impurities has to be less than $1.0 \mathrm{ng} \mathrm{g}^{-1}$. Overall, the results in Table $\mathrm{V}$ indicate that the Ge material is about $9 \mathrm{~N}$ purity. The major impurities $(\mathrm{V}, \mathrm{Cr}$, $\mathrm{Co}, \mathrm{Zr}, \mathrm{Ru}, \mathrm{Pd}, \mathrm{Pb}$, and $\mathrm{Bi}$ ) of definite concentration values found in the $9 \mathrm{~N}$ pure Ge material are shown in Figure 2 with the percentage of their mass fractions. The precision expressed as percentage relative standard deviation (\%RSD) of the signals obtained with multiple sample loadings $(\mathrm{N}=4)$ was determined and found to vary from 4 to $10 \%$ for concentrations between 0.28 to $0.011 \mathrm{ng} \mathrm{g}^{-1}$.

\section{CONCLUSION}

A wet chemical method has been successfully applied to characterize ultrapure germanium of even $9 \mathrm{~N}$ (99.9999999\%) purity for its impurity concentrations. The modifications made to the matrix volatilization setup allowed further control on the contamination of atmospheric gases to the $9 \mathrm{~N}$ pure Ge sample during different stages of the matrix volatilization procedure and resulted in sub parts per billion and parts per trillion levels of process blanks and extremely low detection limits. It then enabled characterization of $9 \mathrm{~N}$ pure $\mathrm{Ge}$ successfully. The reaction temperature $230 \pm 5{ }^{\circ} \mathrm{C}$ was found to be suitable also to remove the Ge matrix from even $9 \mathrm{~N}$ pure Ge material from its impurities quantitatively. More than 60 elements were found to be quantitatively 


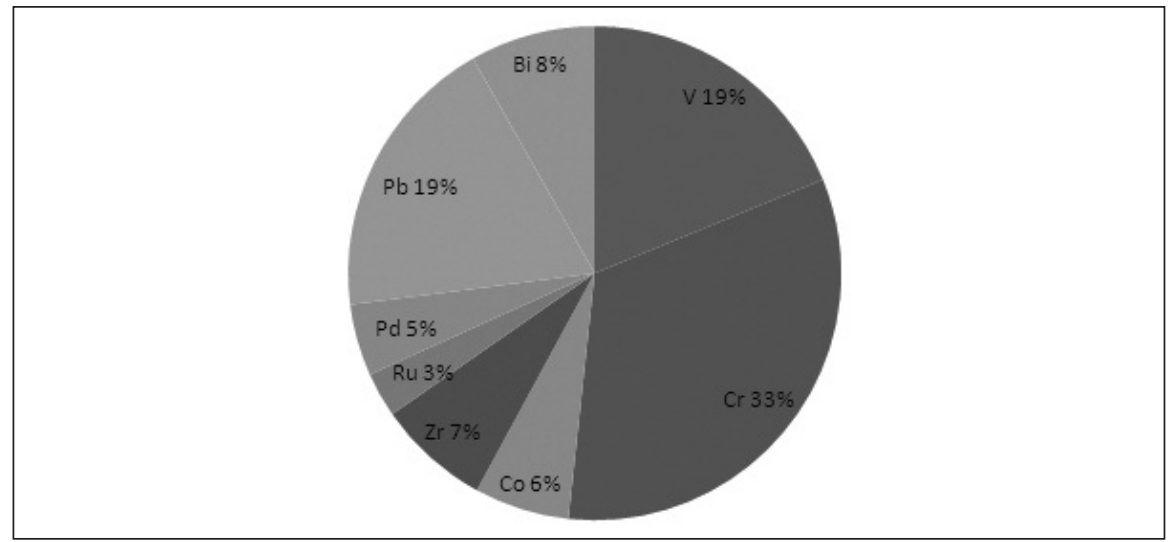

Fig. 2. Major impurities found in $9 N$ pure Ge material with their percentage mass fractions.

separated from the Ge matrix. Precision was found to vary from 4 to $10 \%$ for the element concentrations between 0.28 and $0.011 \mathrm{ng} \mathrm{g}^{-1}$. The limits of detection (LOD) were found to be between 4.6-0.005 $\mathrm{ng} \mathrm{mL} \mathrm{L}^{-1}$ or 1.4-0.002 $\mathrm{ng} \mathrm{g}^{-1}$. Using the proposed method, which involves only a single matrix separation step that does not demand any acidic sample digestion, concentrations of more than 50 impurity elements in ultrapure Ge material $(9 \mathrm{~N})$ were determined with ICP-QMS/GFAAS measurements. It is a further analytical development in an area of materials science for the electronic/ semiconductor industry.

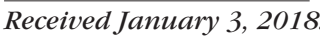

\section{ACKNOWLEDGMENT}

The authors thank Dr. P.D.Naik, Associate Director, NCCCM for his continuous support and encouragement.

\section{REFERENCES}

1. R.D. Baertsch and R.N. Hall, IEEE Trans. Nucl. Sci. 17 (1971) 235.

2. W.E. Drummond, IEEE Trans. Nucl. Sci. 18 (1971) 91.

3. E. Sakai, T.A. McMath and I.L.
Fowler, IEEE Trans. Nucl. Sci. 18 (1971) 228.

4. M.U. Khandaker, International Journal of Fundamental Physical Sciences 1 (2011) 42.

5. J. Derluyn, K Dessein, G Flamand, Y Mols, J Poortmans, and G Borghs, J. Crystal Growth 247 (2003) 237.

6. P. Clauws and E. Simoen, Mat. Sci. Semicon. Proc. 9 (2006) 546.

7. T. Hackbarth, G. Hoeck, H.J. Herzog and M. Zeuner, J. Crystal Growth 734 (1999) 201.

8. M.I. Ginzburg, N.I. Marunina, and E.S. Milenin, Tsvetn. Metall. 1 (1977) 56

9. G.N. Razumova, I.D. Shuba, and I. Vasiliev, Radiokhimiya 12 (1970) 133.

10. E.M. Bykova, M.I. Iglytsin, E.A. Kurkova, D.I. Levinzov, V.I. Sidorov, and V.A. Shershel, Zavod. Lab. 42 (1976) 415.

11. V.G. Pimenov and D.A. Timonin, Vysokochist Vesh-chestvu 1, 149 (1988).

12. E. Sentimenti and G. Mazzetto, J. Anal. At. Spectom. 8 (1993) 89.

13. P. Murugaiyan, Pure Appl. Chem. 54, (1982) 835.

14. V.G. Pimenov, A.N. Pronchatov, G.A. Maksimov, V.N. Shishov, E.M. Shcheplyagin and S.G. Krasnova, Zh. Anal. Khim. 39 (1984) 1636.

15. S. Salomon, V. Jenne and M. Hoenig, Talanta 57 (2002) 157
16. M. Nicolaï, C. Rosin, N. Tousset, Y. Nicolai, Talanta 50 (1999) 433.

17. D. Beauchemin, J.W. McLarent and S.S. Berman., Spectrochim. Acta. 42B (1987) 467.

18. C.L.Luke and M.E. Campbell, Anal. Chem. 25 (1953) 1588.

19. R.L. Ueng, A.C. Sahayam, S.J. Jiang and C.C. Wan., J. Anal. At. Spectrom. 19 (2004) 681.

20. M.A. Reddy, N.N. Meeravali and Sunil Jai Kumar, At. Spectrosc. 30 (2009) 92

21 M.A. Reddy, R. Shekhar and Sunil Jai Kumar, At. Spectrosc. 34(4) (2013) 119.

22. M. Niemela, H. Kola, and P. Peramaki, Analytical Sciences 30 (2014) 735.

23. N.I. Petrova, A.R. Tsygankova, and A.I. Saprykin, Inorganic Materials 51 (2015) 57.

24. Adiseshreddy Meruva, Shekhar Raparthi and Sunil Jai Kumar, Talanta 146 (2016) 259.

25. M.A.Reddy, R.Shekhar, and Sunil Jai Kumar, Talanta 159 (2016) 14-22.

26. Alankar Shrivastava and Vipin B. Gupta, Chronicles of Young Scientists 2 (2011) 21.

27. Physics of Ultra-Pure Germanium, Eugene E. Haller, William L. Hansen and Frederick S. Goulding Lawrence Berkeley Laboratory University of California Berkeley, California 94720 U.S A., 1980/2012. https://escholarship.org/content/ qt7mp4x58b/qt7mp4x58b.pdf. 